\title{
MANAGERIAL COMPETENCY EVALUATION OF VOCATIONAL SCHOOL PRINCIPALS IN MAGELANG
}

\author{
Agnes Deswatun Khasanah \\ Universitas Negeri Yogyakarta \\ Nuchron \\ Universitas Negeri Yogyakarta
}

\begin{abstract}
The purpose of this study was to discover the implementation of managerial competence of vocational school principals in Magelang from the perspective of (1) planning, (2) implementation, and (3) result. This study had a form of evaluation research with discrepancy method. The subjects of this study were four principals and thirty teachers of SMK Ma'arif 1 Ngluwar, SMK Ma'arif Salam, SMK Ma'arif Kota Mungkid, and SMK N 1 Salam. The data were collected using questionnaire and interview. This study used analysis of quantitative descriptive as analysis data method. The result of this study indicated that the planning of principals' managerial competence acquired from questionnaire was in "very good" category with average score 52.70; the implementation of vocational school principals' managerial competence in Magelang based on the questionnaire result was in "very good" category with the average score 127.25; and the result of vocational school principals' managerial competence in Magelang based on the questionnaire was in "very good" category with the average score 34.20 .
\end{abstract}

Keywords: evaluation, managerial competence

Permalink: http://dx.doi.org/10.21831/jpv.v8i3.20893

Contact Agnes Deswatun Khasanah deka.agnes@gmail.com

Universitas Negeri Yogyakarta, Jl. Colombo No. 1, Depok, Sleman 55281, Yogyakarta, Indonesia 


\section{INTRODUCTION}

Magelang declared itself as Vocational School District on May 2, 2014. It then brought an impact on the increasing interest of vocational school (SMK), and finally many students were enrolled in vocational schools. Even private vocational schools were established. Up to 2018, it has been noted that Magelang has 44 vocational schools: there are 3 public vocational schools, and 41 private vocational schools.

The rapid increase of vocational schools number, caused tight competition in the quality of education and competence of principals as the decision makers of all school policies and management.

The importance of principals' leadership in school performance, teacher performance in work, and student learning performance are: (1) creating a positive climate within the school or between the principal and the teacher; (2) leadership of school principals can build teacher professionalism, enthusiasm and sense of unity; (3) the principal's leadership can influence the commitment in teaching the teacher, satisfaction in work, and attitude in work, (4) the leadership of the principal can give a difference to student and affective learning attitudes, and academic results, even if the school environment is minimal academic; (5) a strong and balanced structural leadership, hu-man, political, cultural, and educational dimensions can realize the effectiveness of the school, and (6) the principal needs strong support in learning his leadership and the growth of his professionalism (Cheng, 1997, p. 9).

Regulation of Indonesian Minister of National Education (Permendiknas) Number 13 of 2007 (Menteri Pendidikan Nasional Republik Indonesia, 2007) concerning Standards for Principals of Schools/Madrasah states that Principals (KS) must have five competencies namely: Personality, Managerial Skills, Entrepreneurship, Supervision, and Social Conscience.

The school has the authority to regulate and manage the school fully and independently, so the school pricipals must have five competencies. Refers to the National Education Standards (SNP) which are regulated by Government Regulation (PP) Number 32 of 2013 jo PP Number 19 of 2005, Article 1 paragraph 1 (Presiden Republik Indonesia, 2013); na- tional education standards are the minimum criteria for running the education system in Indonesia.

There are 8 standards, namely: (1) content standards, (2) process standards, 3) graduate competency standards, (4) standards of educators and education personnel, (5) facilities and infrastructure standards, (6) management standards, (7) financing standards, and (8) educational assessment standards. In carrying out school-based management, the principal is assisted by these eight standards as a benchmark for the management success. Thus, later, the results of effectiveness, efficiency, and productivity are expected to be achieved in the implementation of managerial competence. SNP aims to provide signs to school principals in managing education in their respective schools.

Educational failures are caused by inappropriate management, placement of personnel that is not in accordance with the field of expertise, and problems which are not handled by experts, so that the goals of national education to educate the life of the nation through improving the quality of each type and level of education have not been realized (Mulyasa, 2007, p. 6).

The efforts to improve the quality of human resources continue to be made by changing education policy that was originally implemented by the district government, now handled directly by the provincial government or decentralization, through Law No. 23 of 2014, article 12 concerning Regional Government (Presiden Republik Indonesia, 2014). This is done by the central government with the aim of increasing education equity in terms of the competence of educators, education personnel, students, supervisors, and the quality of secondary education at the provincial level. Change in education management is according to Law Number 23 of 2014 concerning Regional Governance (Presiden Republik Indonesia, 2014), namely education policy, curriculum, accreditation, educators and education personnel, as well as education licensing. The establishment of the law on decentralization of education is in line with the regional autonomy policy. Decentralization of education is also a manifestation of regional autonomy itself.

Center for Educational Assessment (Pusat Penilaian Pendidikan/Puspendik) suggests that the current education system gene- 
rally does not match the expected quality. This assessment is based on the students' low ability to answer the vocational high school national exams. Other indicators are skills that are characteristic of vocational education, faith, sense of responsibility, and character that have not received adequate attention. In addition, the increasing number of educated people who are unemployed is also an indicator of the low quality of education. The indication of the low quality of education above is presumably due to the low quality that includes the current education program (curriculum and learning), school administration and management, the current educational staff of the school, the input and development of students, educational facilities and infrastructure, and the low quality of community participation in education. In addition, among the causes of the low quality of education, education policies issued by the government are not in line with matters relating to improving the quality of education (Pusat Penelitian dan Pengembangan Kementerian Pendidikan dan Kebudayaan Repbulik Indonesia, 2015).

Results of a survey conducted by the Working Group on the development of the Principal Quality Standards in the Academic Manuscript of the Principal Qualification and Competency Standards by the National Education Standards Agency (Badan Standar $\mathrm{Na}$ sional Pendidikan/BSNP) in 2006 showed that the performance of principals that had not been as expected. It also emphasized that the results of the research submitted by the director of education staff in the Training of Trainers (ToT) Facilitator candidates for school principals and supervisors on February 6, 2009 showed that of the five competencies of principals namely: (1) personality competence, (2) managerial competence, (3) supervision competence, (4) social competence, and (5) entrepreneurial competency, managerial competence and supervision of principals were still low (Purwanto, 2010, pp. 55-63).

Managerial competencies are needed by principals to: (1) plan schools, (2) design school organizations, (3) manage teachers and staff, (4) manage facilities and infrastructure, (5) maintain school and community relations, (6) manage student affairs, (7) develop curriculum, (8) manage school finance, (9) manage school administration, (10) manage special school service units, (11) develop entrepre- neurship in schools, (12) create a culture and work climate, (13) manage school information systems, (14) manage information technology, (15) manage product / service activities, and (16) conduct school supervision (Kompri, 2017, p. 109).

The implementation of principals' managerial competencies has not been implemented properly according to 16 indicators of managerial competency standards, (2) inhibiting factors: (a) principals do not have competency standards; (b) the lack of experience of the principal; (c) inability to prepare school plans; (d) lack of coordination and cooperation; (e) lack of school facilities and infrastructure; (f) lack of training; and (g) lack of supervision from superiors (Adi, 2016, pp. 1-16).

Administrative competency needs of principals for effective school administration at the high school level in the Southwest GeoPolitical Zone of Nigeria. Learning reveals that the instructional leadership skills needed by school principals for effective school administration include: principals working with teachers to set goals, provide primary facilities, supervise lesson plans, teaching and learning activities, evaluate plans and implement curriculum. It was also shown from the results of research that the main personnel management skills needed by school principals for effective schools included administration: the main motivating staff, encouraging professional staff development, communicating affective with staff, resolving conflicts. It is equally revealed from the research findings needed by financial management experts Effective school administration includes: the basic budget prepared together with staff management, funding sources, storing accurate financial information, providing correct and fair financial positions in schools (Adegbemile, 2011, p. 1).

Based on these problems, it is necessary to conduct research on managerial competence of principals. This study was important to see how far the managerial competency implementation of the principals, which later can be the basis of consideration of the related education office to evaluate and provide alternative solutions on how to improve the managerial competence of principals in the field.

The purpose of this research was to see how far the implementation of managerial competencies of principals in SMK Ma'arif 1 Ngluwar, SMK Ma'arif Salam, SMK Ma'arif 
Kota Mungkid, and SMK N 1 Salam, focusing on understanding how far the implementation of managerial competence in planning, implementation process and the results of the implementation of vocational school principals in Magelang.

Meanwhile the theoretical benefit of this research was to measure the achievement of competence managerial implementation as one of the principal evaluation materials and related official reference materials to improve managerial competence of principals, especially in Magelang. Whereas practically this research was as a reflection of the implementation of managerial competencies that have been conducted, so that the principals can evaluate improvements at various points that were deemed incomplete.

\section{RESEARCH METHOD}

The research method used was quantitative method. This method is used to answer the problem statement questions. The research instrument was made to purify the discussion.

The presentation of the results of this study uses descriptive aspects to present systematically the results of research that has been done so that it is easily understood by the reader. This study procedurally uses a discrepancy evaluation model, or gap through three stages (initial-identification-comparison) with a focus on planning, implementation processes and achievement of results from the principal's managerial implementation. The research focused on SMK Ma'arif 1 Ngluwar, SMK Ma'arif Salam, SMK Ma'arif Kota Mungkid, and SMK N 1 Salam. Respondents in this study were teachers and principals in the schools mentioned above.

This study also used data collection tools in form of instrument validity and instrument reliability. Instrument validity used was construct validity to obtain valid data, measuring what should be measured. After that, there were consultation sessions with experts to decide whether it was feasible to be used. The instrument reliability used was Alpha Cronbach formula, to measure whether it is truly reliable, consistent, or steady.

The technique used was questionnaire data done through fast symptom calculation and variable (M) - (Me) - (Mo) - (SD).

\section{RESEARCH RESULTS AND DISCUSSION}

First, data analysis on the aspects of planning carried out by the principal which includes the vision, mission and objectives of the school. Data in this study were obtained through questionnaires.

In the principal manager's competency planning, the school principal implements the school / madrasa vision. the school does have a vision of the school/madrasah but in its preparation it does not involve many school components and is not replaced regularly. If there is a change in leadership of the principal, the school's vision is not changed. In addition to the vision of the school / madrasah, a school / madrasah mission is also prepared.

Questionnaire data on managerial competency planning aspects of principals were obtained from 20 respondents. The questionnaire has 15 statements. Based on questionnaire data, the lowest ideal score is obtained, 15 and the ideal highest score is 60 .

Based on the results of the questionnaire analysis, it could be seen that the managerial competency planning of the principal was categorized very well indicated by an average value of 52.70. The data obtained from the results of 20 respondents, 2 respondents (10\%) in "not quite good" category, 3 respondents $(15 \%)$ in "good" category, and 15 respondents $(75 \%)$ in "very good" category. Complete can be seen in Figure 1.

The Figure 1 shows that the ability of the principal in managerial planning was in a very good category. This means that the principal's managerial planning ability had a good influence of $75 \%$ on school management. The remaining $25 \%$ was influenced by other factors.

Another factor that was caused by school principals who were less capable of planning was explained more fully in Adi's research, namely: $t$ : (1) the implementation of principals' managerial competencies in Kuala Kampar State 1 and State SMP 4 has not been implemented properly according to 16 standard indicators managerial competence, (2) inhibiting factors: (a) the principal does not have competency standards; (b) the lack of experience of the principal; (c) inability to prepare school plans; (d) lack of coordination and cooperation; (e) lack of school facilities and infrastructure; (f) lack of training; and (g) lack of supervision from superiors (Adi, 2016, pp. 1-16). 


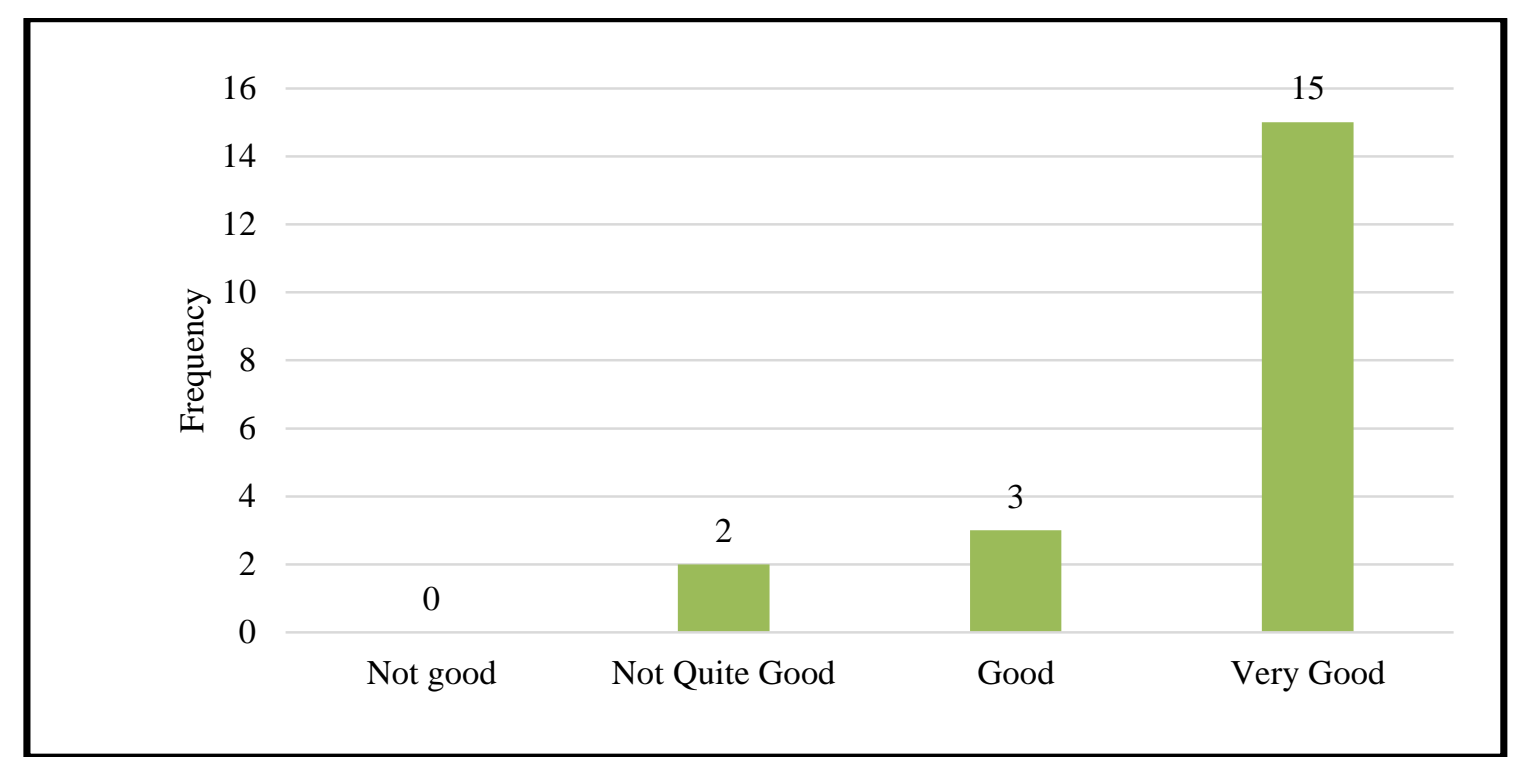

Figure 1. Frequency Distribution of Planning Aspects of Data Results of Principals Managerial Competence

The principal as a manager at a school has a major influence on everything related to school managerial. However, there are also other factors that also influence, including human resources, natural resources, infrastructure, school organizational climate, students' abilities and so on.

In line with the bar chart above, it can also be said that the managerial principal at SMK in Magelang can provide a solution for someone who wants to get education and skills at once, known as Vocational Education, which is explained further:

Vocational or technical training or retraining which given in school or classes under public supervision and control or under contract with a State Board or local education agency, and is conducted as part of program designed to fit individuals for gainful employment as semi-skilled or skilled worker or technicians in recognized occupations (Thompson, 1973, p. 109).

Vocational education certainly must always be developed in line with the demands of the education and workforce in the future. From the results of the comparison of the planning implementation of managerial competencies of principals in related vocational schools, it was found that there was still a gap between the conditions that should be with the actual situation, including: (1) not maximally formulating and developing the vision and mission objectives and objectives of the school maximally, (2) lack of socialization intense to various parties concerned, and (3) no periodic and ongoing review.

Second, data analysis on aspects of implementation which includes school/ madrasah guidelines, school/madrasah organizational structure, implementation of school/madrasah activities, student affairs, curriculum fields, and learning activities, educators and education staff, facilities and infrastructure, finance and funding, the culture and environment of schools/madrasas, community participation and school/madrasah partnerships are obtained through questionnaires.

Research on the implementation of managerial competencies carried out by Indra obtained results namely: The role of the principal who is dominant in implementing School Based Management (SBM) is a managerial role, because the principal can directly choose who is in the school organizational structure. The role of schools in the context of SBM is a driving force for school life. The role is the principal as an educator, manager, administrator, supervisor, leader, entrepreneur, motivator, and climator. The inhibiting factors in the implementation of SBM are communication that has not gone well in school and lack of socialization for the implementation of SBM, while supporting factors are the active role of school citizens in the implementation of SBM and the 
giving of authority or autonomy from the foundation to schools (Lurah \& Haryanto, 2014, pp. 174-187).

The results of the study on the implementation of managerial competencies obtained scores Based on the results of the questionnaire analysis above, it can be seen that the managerial competency planning of principals is categorized very well as indicated by an average value of 127.25. Data obtained from the results of 20 respondents, 2 respondents $(10 \%)$ good categories, and 18 respondents $(90 \%)$ very good categories, this is stated in the figure in Figure 2.

Figure 2 demonstrates that the implementation of managerial competence of principals was in "very good" criteria, which means it provided good influence on teacher performance satisfaction.

Based on average 127.75 respondents' general tendency score calculation, it was found that there were 2 respondents $(10 \%)$ in "good" category, and 18 respondents $(90 \%)$ in "very good" category. Therefore, it indicated principals of the respective schools had implemented well the established standards.

Third, data analysis on aspects of results which include input, process, and output was obtained through questionnaires and interviews. Inputs in the aspects of results in managerial competencies which include infrastructure in general have met the standards of applicable infrastructure. The managerial process of the principal which includes teacher administration that is owned by each teacher includes: making RPP (Learning Implementation Plan), syllabus, and other supporting learning documents. The managerial output of the school principal observed is that the graduates produced are in accordance with the needs of DU/DI so that the level of absorption of graduates is very good. Teacher performance is well monitored and can be seen from good attendance and implementation of learning that is rarely empty. Good teacher performance can have a positive influence on student achievement. The absorption of students in the industry that makes the relationship between schools and DU/DI well interwoven.

Questionnaire data on aspects of the principal managerial competency results were obtained from 20 respondents. The questionnaire has 10 statements. Based on the questionnaire data, the lowest ideal score is 10 and the ideal highest score is 40 . The data obtained from the questionnaire can be seen in Figure 3.

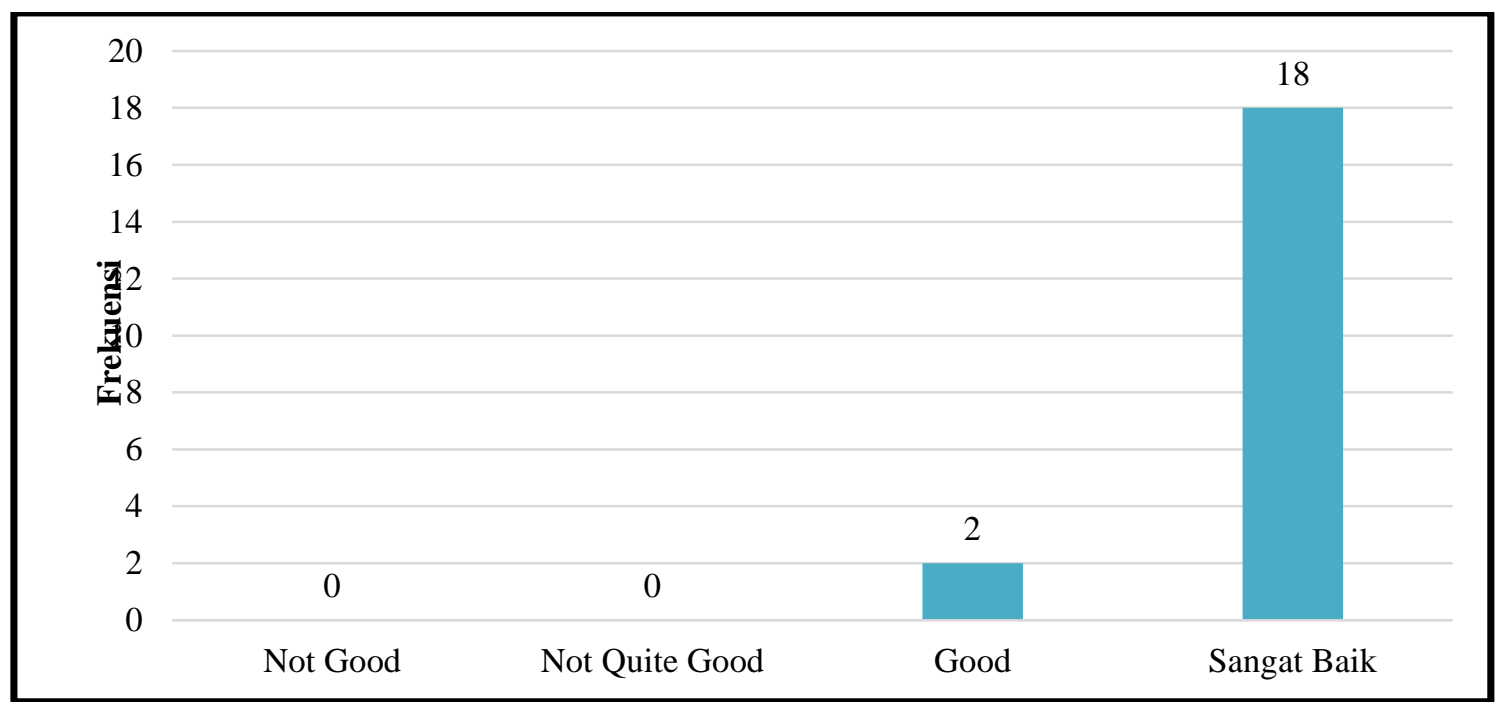

Figure 2. Frequency Distribution of Implementation Aspects of Data Results of Principals Managerial Competence 


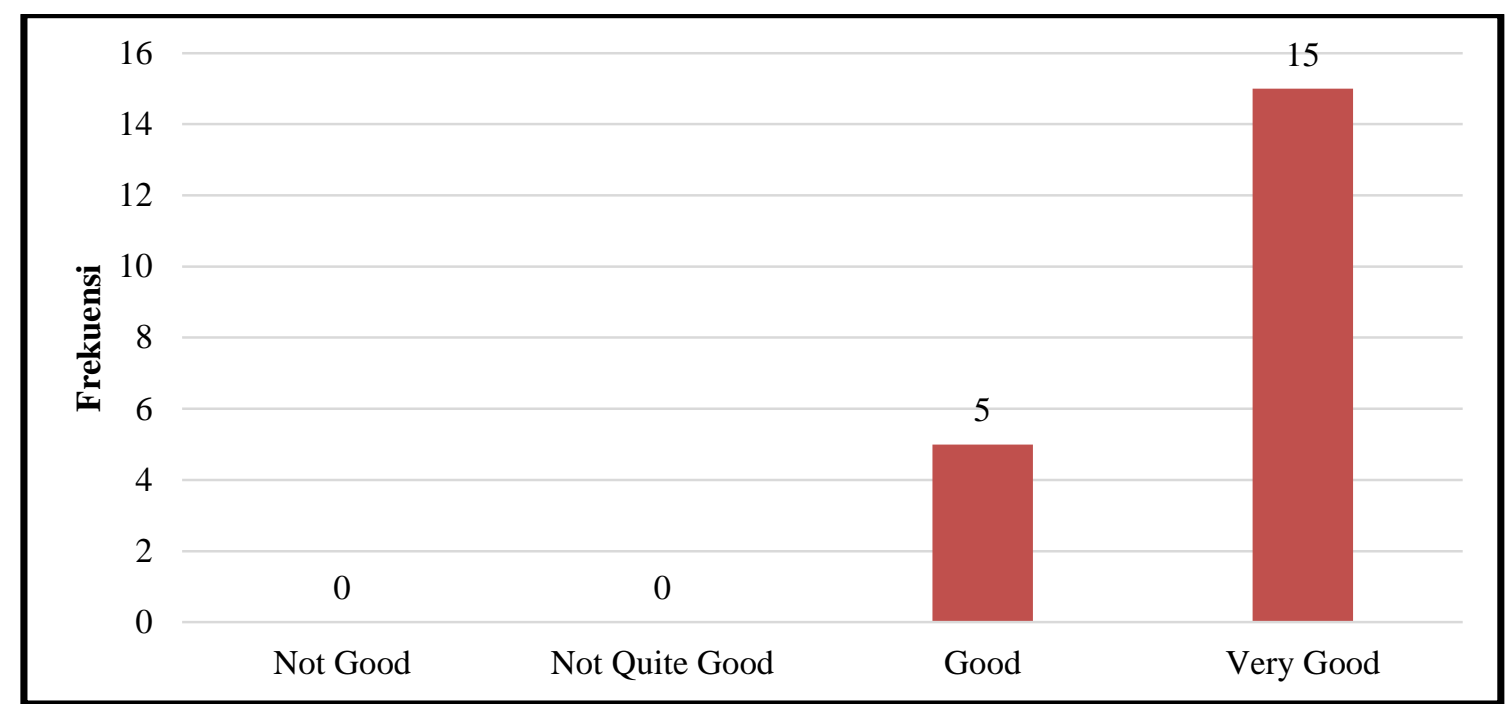

Figure 3. Frequency Distribution of Results Aspects of Data Results of Principals Managerial Competence

From the figure 3 , it could be seen that based on the results of the questionnaire analysis, the results of the managerial competence of principals were categorized very well indicated by an average value of 34.20 . Obtaining data from the results of 20 respondents, 5 respondents $(25 \%)$ were in "good" category, and 15 respondents $(75 \%)$ were in "very good" category.

That data is in line with the research conducted by Arif Jamali namely: contributions given by principals' managerial competencies, school environment, teacher achievement motivation both directly and indirectly to student learning achievement. This means that if the managerial competence of the principal, the school environment and teacher achievement motivation is improved, the quality will contribute positively to the improvement of student learning achievement (Jamali \& Prasojo, 2013, pp. 8-21).

The results of Fitriani's research show that: main managerial competencies have a positive and significant effect on citizenship organizational behavior (OCB), primary managerial competencies have a positive and significant effect on teacher productivity, principals managerial competence has a positive and significant effect on interpersonal communication. Interpersonal communication has a positive but not significant effect on civic organizational behavior (OCB), interpersonal communication has a positive but not significant effect on teacher productivity (Harahap \& Rusdinal, 2017, p. 1).

The results of the managerial output of the principal included graduates produced, teacher performance, student achievement, and relations with DU/DI. These schools were able to produce graduates that are in line with the needs of DU/DI. They were also able to stimulate teachers to improve performance. Learning achievements of both academic and non-academic students must also increase. In addition, DU/DI's trust in schools increased as evidenced by the absorption of students in DU/DI.

However, from the results of comparative analysis of the results of principals' managerial competency aspects, it was found that: 1) there were several teachers who taught subjects that were not suitable with their educational background, 2) there was no gap between the process and results of implementation of activities, and 3) no there was gaps in output results.

\section{CONCLUSION}

Based on the discussion and analysis of research results, it can be concluded as follows:

Managerial competencies of principals of both state and private vocational schools in Magelang were related to the managerial planning ability of the principal, the managerial ability to implement the principal, and the 
ability of the principal to achieve managerial results.

First, the aspects analyzed in the planning process were the school's vision, mission and goals. Generally, it was categorized as "very good" with an average acquisition of 52.70 although there were still some gaps such as the vision, mission and goals of the school that had not been maximally developed, there was lack of socialization and there had been no regular improvement.

Second, the implementation of managerial competence in schools covering all elements of the school proved was very well proven with the results of satisfying average score reaching 127.25. Even in this case there was no gap starting from the guidelines for implementation, implementation in accordance with the guidelines, school activities, student activities, implementation of curriculum, infrastructure, and relations with outside parties.

Third, the results of the data processing that the results of the implementation of the principal's managerial competency also showed "very good" category with an average value of 34.20. Some of the outputs of these competencies included graduates produced, teacher performance, students' achievements, and relationships with DU / DI.

From these conclusions, several suggestions arose: managerial competence of principals needed to be improved was the problem of planning, which must increase socialization of HR about work programs, provide training in soft skills and skills, be alert and ready to receive all information from the relevant government, and proactively coordinate with various parties related to LSP.

Then related to the problem of implementation, the school should recruit teachers who could fulfill the needs of the school and in accordance with the required competencies.

Moreover, to improve the results school outputs, dual system education (PSG) which allowed teachers or students to study directly in the industry must be done. Hence, there were coherence between school and industry, adequate infrastructure provision, and education quality improvement.

\section{REFERENCES}

Adegbemile, O. (2011). Principals' competency needs for effective schools' administration in Nigeria. Journal of Education and Practice, 2(4). Retrieved from

https://www.iiste.org/Journals/index.php /JEP/article/view/436

Adi, A. (2016). Implementasi kompetensi manajerial kepala sekolah kecamatan Kuala Kampar Kabupaten Pelalawan Propinsi Riau. Jurnal Akuntabilitas Manajemen Pendidikan, 4(1), 1. https://doi.org/10.21831/amp.v4i1.8194

Cheng, Y. C. (1997). Instructional leadership and students' educational outcomes in Hong Kong secondary schools. In Annual Conference of the Hong Kong Educational Research Association.

Harahap, F., \& Rusdinal, R. (2017). The influence of principal managerial competency toward teachers productivity with mediation of organizational citizenship behavior and interpersonal communication. In Proceedings of the 2nd International Conference on Educational Management and Administration (CoEMA 2017).

Paris, France: Atlantis Press. https://doi.org/10.2991/coema17.2017.50

Jamali, A., \& Prasojo, L. D. (2013). Pengaruh kompetensi manajerial kepala sekolah, lingkungan, motivasi guru, terhadap prestasi siswa SMA Muhammadiyah kota Yogyakarta. Jurnal Akuntabilitas Manajemen Pendidikan, 1(1), 8-21. Retrieved from https://journal.uny.ac.id/index.php/jamp/ article/view/2309/1912

Kompri. (2017). Standardisasi kompetensi kepala sekolah: pendekatan teori untuk praktik profesional. Jakarta: Kencana.

Lurah, I. H. S., \& Haryanto, H. (2014). Peran kepala sekolah dalam penerapan manajemen berbasis sekolah (MBS) di SDIT Jabal Nur Gamping, Sleman.

Jurnal Akuntabilitas Manajemen Pendidikan, 2(2). https://doi.org/https://journal.uny.ac.id/in dex.php/jamp/article/view/2447

Menteri Pendidikan Nasional Republik Indonesia. Peraturan Menteri Pendidikan Nasional Nomor 13 Tahun 2007 tentang 
Standar Kepala Sekolah/Madrasah (2007).

Mulyasa, E. (2007). Menjadi kepala sekolah profesional. Bandung: Remaja Rosdakarya.

Presiden Republik Indonesia. Peraturan Pemerintah Republik Indonesia Nomor 32 Tahun 2013 tentang Perubahan Atas Peraturan Pemerintah Nomor 19 Tahun 2005 tentang Standar Nasional Pendidikan (2013).

Presiden Republik Indonesia. Undang-Undang Republik Indonesia Nomor 23 Tahun 2014 tentang Pemerintahan Daerah (2014).

Purwanto, N. A. (2010). Strategi mengembangkan kompetensi manajerial kepala sekolah. Jurnal Manajemen Pendidikan: Jurnal Ilmiah Adminstrasi, Manajemen Dan Kepemimpinan Pendidikan, 2(VI). Retrieved from https://journal.uny.ac.id/index.php/jmp/a rticle/view/3643

Pusat Penelitian dan Pengembangan Kementerian Pendidikan dan Kebudayaan Repbulik Indonesia. (2015). Penilaian yang berkualitas untuk pendidikan yang berkualitas. Jakarta: Kementerian Pendidikan dan Kebudayaan Repbulik Indonesia.

Thompson, J. F. (1973). Foundations of vocational education social and philosophical concepts. Madison: Prentice-Hall, Inc. Englewood Cliffs. 